\title{
Trompe l'œil: an approach to promoting art tourism (case study: Shiraz city, Iran)
}

\author{
Zahra Nikoo, Neda Torabi Farsani and Mohamadreza Emadi
}

\section{Zahra Nikoo,}

Neda Torabi Farsani and Mohamadreza Emadi all are based at the Art University of Isfahan, Isfahan, Iran.
Received 26 September 2019 Revised 14 November 2019 2 April 2020

Accepted 9 April 2020

(c) Zahra Nikooa, Neda Torabi Farsani and Mohamadreza Emadi. Published in the Journal of Tourism Futures. Published by Emerald Publishing Limited. This article is published under the Creative Commons Attribution (CC BY 4.0) license. Anyone may reproduce, distribute, translate and create derivative works of this article (for both commercial and non-commercial purposes), subject to full attribution to the original publication and authors. The full terms of this license may be seen at http://creativecommons.org/ licences/by/4.0/legalcode

\begin{abstract}
Purpose - Trompe l'oeil as a novel art technique can not only promote art tourism but can also transform the landscape of a city into a platform for negotiation. Furthermore, trompe l'oeil aims to create a joyful, entertaining, new experience and an interactive environment for tourists in the cities. This paper highlights the introduction of trompe l'oeil as a new tourist attraction in Shiraz (Iran). Moreover, the goals of this study are to explore the role of trompe l'oeil (three-dimensional [3D] street painting) in promoting art tourism, to investigate the tendency of tourists toward experiencing art tours and trompe l'oeil and to determine the priority of trompe l'oeil themes from the domestic tourists' perspective.

Design/methodology/approach - Qualitative and quantitative methods were used in this research study.

Findings - On the basis of the results of this study, it can be concluded that domestic tourists are eager to experience art tours and trompe l'oeil attractions and activities, except for buying and wearing 3Dprinted clothes. In addition, trompe l'oeil on street floors and walls with funny, joyful and cultural-artistic and national-historical themes is more attractive for them.
\end{abstract}

Originality/value - No significant academic work has been undertaken in the field of art tourism to evaluate the attitude of tourists toward the trompe l'oeil attractions and activities.

Keywords Tourism, Art tourism, Street art, Trompe l'oeil

Paper type Research paper

\section{Introduction}

Art brings humans from individual life to social life and the main objects of art are aesthetics and showing reality. Art tourism is niche tourism in which art is the primary motivation of travel. According to Kihien's (2010) definition, the concept of art tourism seems new, but it is definitely an old form of niche tourism and for centuries the arts and culture have been greatly appreciated in many societies. In art tourism, people travel to visit and to engage in activities related to art festivals, concerts and events and to explore famous museums. In addition, Baur (2014) noted that "art tourism allows both the artist in the secondary art market and the buyers of 'Fine Art' to mutually benefit". Nowadays, public art, especially graffiti, murals and trompe l'oeil are attractions for promoting art tourism that not only attract visitors to a destination to observe the beauty and the art of artists but are also a way to express the politic and social issues and identity of the community (Becker, 2004; Kosari, 2010).

This paper examines the issue of art tourism and highlights trompe l'oeil (three-dimensional [3D] street painting) to diversify urban tourism and promote new niche tourism in the city.

William Michael Harnett started working on trompe l'oeil in 1870 and other artists continued his work (Lis, 2006). Trompe l'oeil, which is a French word that means deceive the eye, is an art technique that uses realistic imagery to create the optical illusion that the depicted objects exist in three dimensions (Doswell, 1997; Hanrahan, 1998; Ronen and Biberman, 2005; Wade, 2009). 
Iran is a land of art, and it is known as a cultural and artistic destination, but in the field of trompe l'oeil, there is no significant work. As diversifying tourism is a priority in the 20-year vision policy document of the Ministry of Cultural Heritage, Tourism and Handicraft Organization of Iran, using trompe l'oeil in art street, graffiti and murals not only can increase the number of tourists, but as a new experience also creates an interactive environment for tourists in a destination. Furthermore, trompe l'oeil is very close to reality and allows tourists to touch the pictures and engage with the images and bring them a lot of fun and joy. Moreover, applying trompe l'oeil in urban graphics can change the urban environment into an open-air museum that attracts tourists and benefits both the host society and the tourists.

As Shiraz is known as a city of culture, literature and art, this study was conducted in Shiraz and the initial attempt of this research is to explore the role of trompe l'oeil (3D street painting) in promoting art tourism and to investigate the domestic tourists' attitudes toward trompe l'oeil in the case study of Shiraz, Iran.

\section{Literature review}

Public art is a way of enhancing or personalizing impersonal spaces and aims to activate civic dialogue or provide a vehicle for the community to express its identity (Becker, 2004). Tsilimpounidi and Walsh (2011) noted that street art as public and postmodern art has boomed in Athens in recent years and transformed the fixed landscape of a city into a platform for negotiation, response to human rights issues, resistance and dialogue. Skinner and Jolliffe (2017) believed that street art such as murals are more important than a simple tourist attraction or accidental aspect. Street art tries to reflect something about the heritage, identity and politics of the locations.

The results of Jażdżewska (2017) illustrated that from the tourists' perspective, street art such as murals can be a tourist attraction in a post-industrial city like Łódź (Poland).

Street art as a visual culture is an urban art movement (Irvine, 2012). A street art project was carried out in the city of Melbourne, Australia, to curtail the output of artists and restrict them to council-sanctioned spaces, where the emphasis is on high-quality work (Stewart, 2008). By performing this street art project, graffiti is used to promote the city on its tourist information website, and Melbourne is known as a culture capital, graffiti capital and openair art gallery, which can attract culture vultures of all ages of visitor, just by walking the streets (Stewart, 2008). Rojo and Harrington (2014) looked into a project entitled Underdogs as an international working platform based in Lisbon and Sintra in Portugal to create space within the contemporary art scene for artists connected with new languages of urban visual culture and as fun for tourists. In addition, Mokras-Grabowska (2014) introduced Łódź (Poland) as a new tourism space: art tourism space because of its murals. She mentioned that the interpretation of murals needs mental effort, aesthetic senses and engagement of audiences.

Flessas and Mulcahy (2018) described that street art, on the one hand, increases the commercial value of streets, enhances the cityscape, creates new local art markets and attracts tourists, and on the other hand, contributes to the gentrification of an area with the result that conventional ways of conceiving of street art have begun to pose new challenges to concepts of crime and property.

Andrea and Trudie (2017) argued that art street as a public good and a vehicle for beautifying and revitalizing neglected parts of the city can be a strategy to foster urban tourism.

It is noteworthy that some cities are pioneers for promoting street art and graffiti and attract internationally known street artists who travel to these destinations to exhibit their works and encourage tourists and visitors to visit those areas (Robinson et al., 2011): Berlin, Germany; 
Lyon, France; London, (Harvey, 2006) and Manchester, UK (Robinson et al., 2011), Melbourne, Australia (Stewart, 2008), Barcelona, Spain, Rome, Florence and Milan, Italy (Bensalhia, 2015) constitute good examples. Organizing street art tours and workshops (Free Tours by Foot, 2017), providing street art maps and brochures, training street art guides, establishing graffiti museums in art streets, etc. are strategies for promoting art tourism in art streets. Moreover, some destinations attract tourists with color. For example, Chefchaouen, Morocco, is known for its striking blue houses (Behrooz, 2017). In addition, colorful houses in Costa Nova, Portugal, are more examples in this regard. Furthermore, 3D chalk art (chalk street art) is now a rapidly growing art form and attracts tourists to a destination (Pinterest, 2017).

Rolfs (2018) examined the relationship between street art and US museums and noted that museums attempt to transfer of energy and the value of street art as transgressive urban art to new audiences. Molnár (2018) indicated that street art can play an axial role in city branding, fashion design, guerrilla marketing campaigns and tourist attraction as an alternative in city tours. Furthermore, Yan et al. (2019) introduced street art as an alternative attraction in Berlin, Germany. Also, they argued that experiencing sadness related to the history of the Berlin wall and aesthetic pleasure aroused by the murals are sense which has transferred to tourists. Lastly, Forte and De Paola (2019) suggested street art as a strategy for attracting tourists, motivating social action and the prosperity of local economies.

It is worth mentioning that art tourism and street art are current considerations in Iran.

Kosari (2010) outlined graffiti as a protest art and stated that graffiti as a new phenomenon of public art can be a way to express ideas and views regarding politic and social issues, especially for youth. In addition, the result of his study in Iran indicated that the tendency toward graffiti is more visible among young people in the middle class and in boys. However, Daliri (2011) suggested that local communities should be involved in art projects and educating locals in trompe l'oeil, and engaging them with an art project can be a means for local economic prosperity and a tourist attraction.

Mousavi (2013) highlighted that Iran has great potential in art tourism, especially graffiti, murals and trompe l'oeil, and that they can be used as a tourist attraction. Furthermore, Karimi (2017) noted that murals in Tehran (Iran) not only express the Islamic Republic ideology but also turned into a tourist attraction.

Nevertheless, no significant work has been undertaken in the field of art niche tourism to investigate the attitude of tourists toward the trompe l'oeil (3D street painting) attractions and activities. Besides, up to this time, there exists no solid research that takes art tourism into consideration in a case study of Shiraz. Figure 1 illustrated two samples of trompe l'oeil (3D street painting) in Shiraz city.

\section{Figure 1 Trompe l'oeil (3D street painting) in Shiraz city}

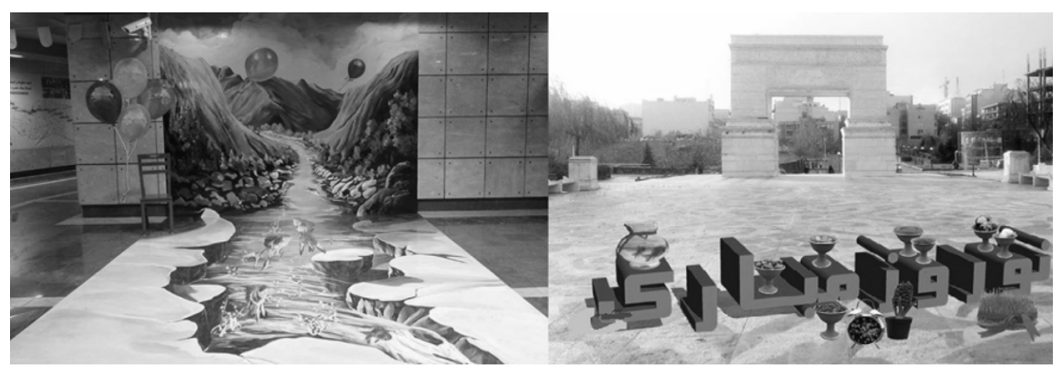

Source: Photo by authors 


\section{Methodology}

This study was conducted in the city of Shiraz, Iran, which is a city in the southwest of Iran and is the capital of Fars Province. The city was an ancient town and known as the capital of Persian art and culture and has great potential for cultural and art tourism (Torabi Farsani et al., 2018a). Shiraz is a city of more than 4,000 years old, and in the Achaemenid era, the city was on the way from Susa to Persepolis and Pasargadae.

The combine method (qualitative and quantitative) was used in the present study. The first phase presents a summary of works being carried out in public art, street art, trompe l'oeil and tourism. The primary goal of this study is to explore the role of trompe l'oeil (3D street painting) in promoting art tourism. In addition, as a study of the audience is a key component for the development of a new product in a destination (Robinson and Novelli, 2005; Masoud et al., 2018; Bahadori et al., 2018; Farsani et al., 2017), we also investigate domestic tourists' attitudes toward trompe l'oeil in the case study of Shiraz, Iran, as an important audience group.

To achieve these goals, we designed one research question $(R Q)$ and three hypotheses:

$R Q 1$. How can trompe l'oeil promote art tourism in a destination?

H1. Participating in art tours is desirable for tourists.

H2. Trompe l'oeil sites and activities in the case study of Shiraz, Iran, are desirable for tourists.

H3. At least two of the variables (themes for public art, especially trompe l'oeil from the tourists' perspective) are significantly different from each other.

Art tourism, trompe l'oeil, public art and street art are current considerations in Iran. We used a qualitative method to explore the role of trompe l'oeil (3D street painting) in promoting art tourism. An in-depth, structured interview format was conducted with 35 experts in the field of art and tourism and with managers of tourism companies who were familiar with art tourism to reveal their ideas descriptively. According to some authors (Boyce and Neale, 2006; Torabi Farsani et al., 2018b), this method allowed the researchers to explore experts' perspectives on the subject. The empirical part of present study was done between October 2017 and November 2017. Face-to-face interview technique and a snowball sampling method were used. Interviews were done until an information saturation point was reached (Sandelowski, 1995; Torabi Farsani et al., 2018b). Axial and selective coding was used to analyze the data. As the interview was conducted by the small sample size and a case study was selected, the outcome of qualitative approach cannot be generalized to other areas of Iran or to other countries. However, the study is important in identifying current thinking and innovative ideas regarding the role of trompe l'oeil (3D street painting) in promoting art tourism as a new product of tourism in Iran and around the world.

Then, according to observation and the literature review, activities and attractions of street art with an emphasis on trompe l'oeil were listed (Table 1) and a questionnaire (five-point Likert scale) was designed to investigate the tendencies of tourists toward trompe l'oeil. Regarding this, the questionnaire was focused on domestic tourists and was distributed in the city (around attractions, hotels, airports, etc.). Morgan's table was used for determining sample size, and it illustrated that the sample size should be 384 people. Thus, 400 questionnaires were distributed, and 385 questionnaires were back to us.

\section{Results}

As mentioned above, face-to-face interviews were conducted with experts in the field of tourism, art and with managers of tourism companies who were familiar with art tourism and trompe l'oeil and collecting data continued till saturation point $(n=35)$. The qualitative method was used to identify current thinking regarding the role of trompe l'oeil (3D street painting) in 
Selective coding

Environmental graphic design

(visual quality)

Audience-centric
Axial coding

Visual attractiveness

Diversity of urban space

Beautification and improvement of urban space

Socio-cultural knowledge transfer

Introducing urban spaces suitable for tourism

Interactive sites

\section{Open coding}

As an artifact tourist attraction, it can attract tourists to a destination

Creating a joyful and entertaining environment for tourists

Creating a different attraction for tourists

Creating a new experience for tourists

Beautification of urban space to attract tourists

Creating visual attractiveness for tourists and the local community

Creating beauty in architecture to attract tourists

Expressing cultural issues of the local community to tourists

Familiarity of tourists with the culture and lifestyle of the host community

Expressing historical topics for tourists in the language

of the image

A tool for introducing artists and art professionals to tourists

Promoting art tourism in the destinations

A tool for expressing social issues to tourists and audiences

A stimulus for the photographic activity at the destination A tool for introducing various destinations and places The creation of 3D painting open-air museums to attract tourists

3D painting has more impact than 2D painting on tourists

Transferring messages to tourists and audiences

promoting art tourism as a new product of tourism in Iran and around the world. Open, axial and selective coding was used to analysis data, and the results illustrated that trompe l'oeil creates environmental graphic design and visual quality, which can attract tourists to a destination. Furthermore, trompe l'oeil can be a tool for socio-cultural knowledge transfer for both tourists and the local community and can be a strategy to introduce suitable urban spaces for tourism, which can promote tourism marketing, especially art tourism. Moreover, trompe l'oeil develops an audience-centric content strategy and can create interactive sites for tourists, audiences and the local community (Table 1).

In the next phase, the tendency of domestic tourists regarding trompe l'oeil as an attraction was studied. In this regard, 385 responses were coded for data analysis. Cronbach's $\alpha$ calculated 0.7 , which indicated good reliability. The output of descriptive statistics demonstrated that among the survey participants, 49.6\% (191) were male and 50.4\% (194) were female; the majority of domestic tourists were between 15 and 25 years of age (31.7\%) (Figure 2). Based on the result of the descriptive analysis (Likert scale ranging from very low to very high) (Table 2), participating in art tours were desirable for $58.4 \%$ of respondents; $77.7 \%$ of tourists are interested in visiting street art with trompe l'oeil (3D street painting). In addition, $68 \%$ of the respondents would like to participate in art festivals, with an emphasis on trompe l'oeil. Moreover, analysis of the data indicates that $71.4 \%$ of the tourists find that visiting 3D painting museums are attractive for them. Furthermore, $74.6 \%$ of the tourists enjoy seeing and touching and taking a photo of trompe l'oeil art. And, $47.8 \%$ of tourists are eager to buy 3D paintings. Further, 38\% of them claim to be interested in buying and wearing 3D-printed clothes. Observing the trompe l'oeil of artists from other countries in Shiraz, Iran, was mentioned by $60.5 \%$ of tourists (Table 2 ). 


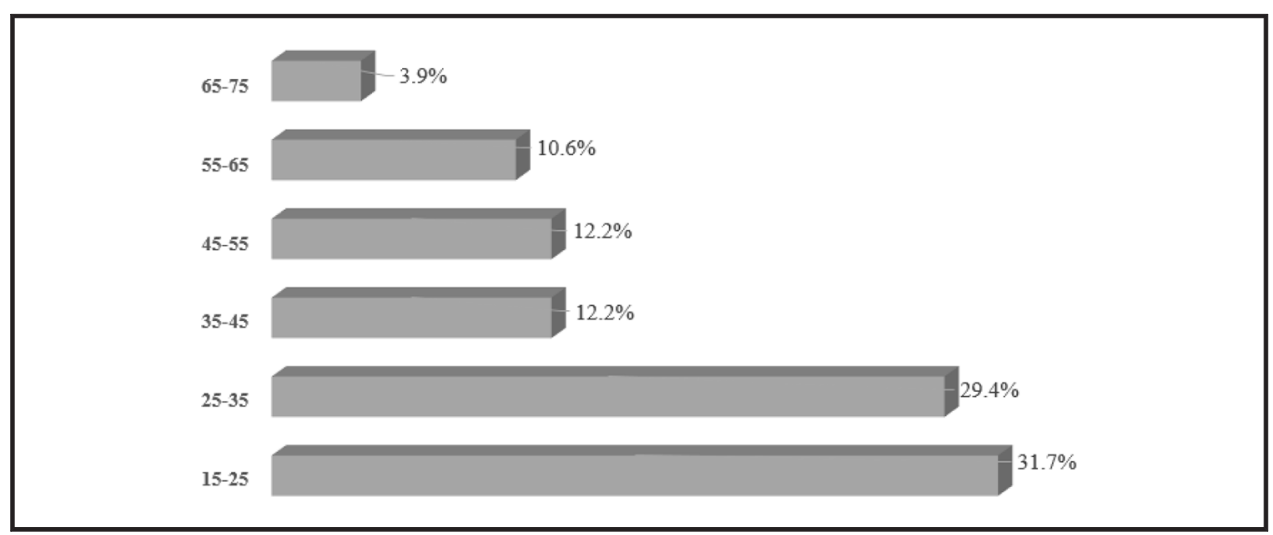

In the next phase, we tested $\mathrm{H}_{1}, \mathrm{H} 2$ and $\mathrm{H}_{3}$ :

H1. Participating in art tours is desirable for tourists.

H2. Trompe l'oeil sites and activities in the case study of Shiraz, Iran, are desirable for tourists.

H3. At least two of the variables (themes for public art, especially trompe l'oeil from the tourists' perspective) are significantly different from each other.

The clearest result of one sample $t$-test $(\mu>3$ and Sig $<0.05)$ indicated that participating in art tours and trompe l'oeil sites and activities in the case study of Shiraz are desirable for domestic tourists, and therefore, $\mathrm{H} 1$ and $\mathrm{H} 2$ were accepted (Table 2). However, an analysis of the data with Table 2 illustrated that, among the activities, the respondents are not interested in buying and wearing 3D-printed clothes.

It is noteworthy that a Friedman test was used to analyze the priority of the themes for public art, especially trompe l'oeil from the tourists' perspective (H3). Analysis of the data (Tables 3, 4, 5) illustrated that the null hypothesis is rejected, and it can be concluded that there are differences between variables. Among the variables regarding the places of drawing trompe l'oeil, the respondents mentioned that they are interested in trompe l'oeil on the street floor, on walls, on objects and on the body. In addition, trompe l'oeil with relaxing, funny and joyful themes are more attractive emotional themes for public art and trompe l'oeil from the tourists' perspective. Moreover, tourists prefer cultural-artistic and nationalhistorical themes for trompe l'oeil.

\section{Conclusion}

Art tourism is niche tourism in which art is the primary motivation of travel, and art tourism needs new products and innovation to survive in competitive tourism marketing. Recently, trompe l'oeil has emerged as a new art technique tries to attract tourists to a destination and promote art tourism.

The aim of the present paper was to explore the role of trompe l'oeil (3D street painting) in promoting art tourism as a new product of tourism in Iran and around the world. Regarding this, interviews were conducted by experts, and the clearest result of the axial coding is that trompe l'oeil aims to attract tourists to a destination and foster art tourism through creating visual attractiveness, diversity of urban spaces and beautification and improvement of them. It can be said that our results reinforce the research of Andrea and Trudie (2017). According to Becker (2004), public art attempts to activate civic dialogue or provide a vehicle for the community to express its identity, 


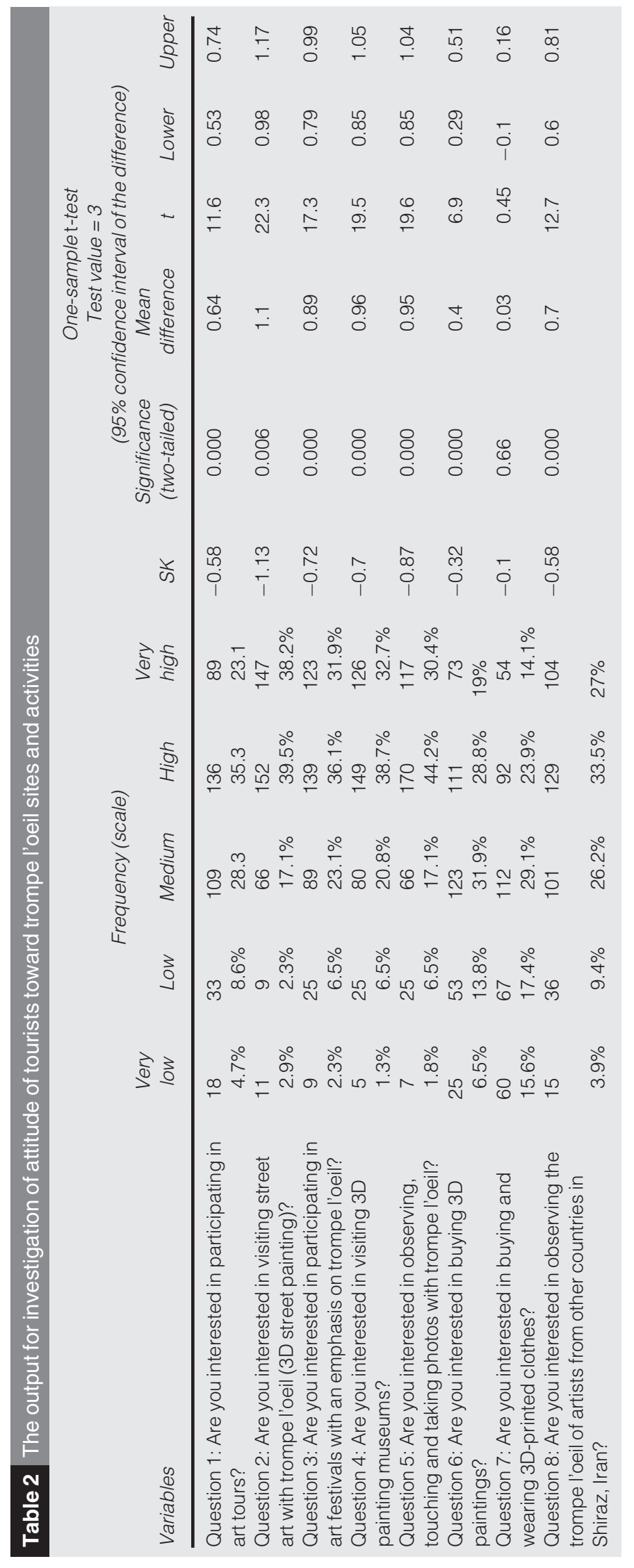




\begin{tabular}{|c|c|c|c|}
\hline Variables & Mean rank & $S D$ & Test statistics \\
\hline I am interested in trompe l'oeil on the street floor & 1.8 & 0.807 & $N=385$ \\
\hline I am interested in trompe l'oeil on walls & 1.68 & 0.789 & Chi-Square $=577.5$ \\
\hline I am interested in trompe l'oeil on the body & 3.56 & 0.808 & $d f=3$ \\
\hline I am interested in trompe l'oeil on objects & 2.96 & 0.761 & Asymptotic significance $=0.00$ \\
\hline
\end{tabular}

\begin{tabular}{|c|c|c|c|}
\hline Variables & Mean rank & $S D$ & Test statistics \\
\hline I am interested in trompe l'oeil with scary and exciting themes & 3.25 & 1.121 & $N=385$ \\
\hline I am interested in trompe l'oeil with funny and joyful themes & 2.27 & 0.996 & Chi-square $=190.157$ \\
\hline I am interested in trompe l'oeil with relaxing themes & 2.06 & 0.962 & $d f=3$ \\
\hline I am interested in trompe l'oeil with memorable themes & 2.42 & 1.007 & Asymptotic significance $=0.00$ \\
\hline
\end{tabular}

\begin{tabular}{|c|c|c|c|}
\hline Variables & Mean rank & $S D$ & Test statistics \\
\hline I am interested in trompe l'oeil with cultural-artistic themes & 1.68 & 0.800 & $N=385$ \\
\hline I am interested in trompe l'oeil with national-historical themes & 1.80 & 0.813 & Chi-Square $=561.462$ \\
\hline I am interested in trompe l'oeil with religious themes & 3.49 & 0.836 & $\mathrm{df}=3$ \\
\hline I am interested in trompe l'oeil with socio-political themes & 3.03 & 0.759 & Asymptotic significance $=0.00$ \\
\hline
\end{tabular}

and the results of this study confirmed it and indicated that trompe l'oeil as a public art expresses social and cultural issues of the local community to tourists. In addition, Tsilimpounidi and Walsh (2011) argued that street art as a public and postmodern art form can transform the fixed landscape of a city into a platform for negotiation, response to human rights issues, resistance and dialogue, and our results also suggested that 3D painting as street art has more impact than two-dimensional (2D) painting on tourists and can transfer messages to tourists and audiences. We believe that this allows us to conclude that trompe l'oeil as a public and street art creates joyful, entertaining, new experiences and an interactive environment for tourists in a destination.

Lastly, because the development of trompe l'oeil as a new product in a destination needs a study of the audience (Robinson and Novelli, 2005), we also investigated domestic tourists' attitudes toward trompe l'oeil in the case study of Shiraz, Iran, using a quantitative method. On the basis of the results of this research, it can be concluded that domestic tourists are interested in participating in art tours and trompe l'oeil sites and activities, except for buying and wearing 3D-printed clothes. The further analysis illustrated that tourists are more interested in trompe l'oeil on the street floor and on walls and that relaxing, funny and joyful themes in trompe l'oeil are more attractive than emotional themes for them. Besides, the tourists prefer cultural-artistic and national-historical themes for trompe l'oeil. It is noteworthy that Shiraz is known as a city of culture and art; therefore, these themes are in accordance with the city's identity. Obviously, local managers have to pay attention to the trends and demands of tourists for promoting art tourism in the study area. 
In recent years, trompe l'oeil has only been implemented on the floor and walls of hospitals and metro stations and is not known as a new tourism product, while on the basis of the results of this research, it can be concluded that tourists welcome art tourism, art tours, trompe l'oeil, public art and street art in the city of Shiraz, and they are interested in trompe l'oeil, which offers visitors the opportunity to have a new experience.

It is noteworthy that the creative tourism - known as third tourism generation - with the slogan of "Less museums, more squares" has an emphasis on a deeper interaction with tourists in a destination. Obviously, promoting trompe l'oeil (3D street painting) in tourism destination can be a step toward achieving this slogan for future.

Our research suggests several areas for future research. It suggests a study on identifying the factors that contribute to promoting art tourism, with an emphasis on trompe l'oeil in the case study. Moreover, appropriate street location studies for creating 3D chalk art (chalk street art) is another recommendation for the future of art tourism in Shiraz city. Last but not the least, suggestion is a study regarding the creation of 3D painting open-air museums to attract tourists in Shiraz.

\section{References}

Andrea, S. and Trudie, W. (2017), "Tourism-management; street art; tourism-social aspects; public spaces; city planning; public art”, in Craig, L., Sebastian, F., Albrecht, J.N. and Coetzee, W. (Eds), CAUTHE 2017: Time for Big Ideas? Re-Thinking the Field for Tomorrow, Department of Tourism, University of Otago, Dunedin, pp. 512-514.

Bahadori, S.R., Torabi Farsani, N. and Shafiei, Z. (2018), "Tourists' views on Islamic spiritual tours (case study: Yazd, Iran)", Journal of Islamic Marketing, Vol. 10 No. 1, pp. 323-335, doi: 10.1108/JIMA-05-20170055.

Baur, P. (2014), "Inefficiency in the market for 'fine art': how this market inefficiency promotes 'art tourism' in South Africa", African Journal of Hospitality, Tourism and Leisure, Vol. 3 No. 2, pp. 1-18.

Becker, J. (2004), "Public art: an essential component of creating communities", Americans for the Arts, Printed in the United States, available at: www.americansforthearts.org/sites/default/files/ PublicArtMonograph_JBecker.pdf (accessed 11 November 2017).

Behrooz, A. (2017), "The 10 most beautiful towns in Morocco", available at: https://theculturetrip. com/africa/morocco/articles/the-10-most-beautiful-towns-in-morocco/ (accessed 11 November 2017).

Bensalhia, J. (2015), "10 Street artists in Italy to watch right now", available at: www.italymagazine.com/ featured-story/10-street-artists-italy-watch-right-now (accessed 11 November 2017).

Boyce, C. and Neale, P. (2006), Conducting in-Depth Interviews: A Guide for Designing and Conducting in-Depth Interviews for Evaluation Input, Pathfinder International, Watertown, MA.

Doswell, R. (1997), Tourism: How Effective Management Makes Different Butterworth and Heinemann, Butterworth Heinemann, Amsterdam.

Farsani, N.T., Shafiei, Z., Adilinasab, A. and Taheri, S. (2017), "An investigation of tourists' attitudes towards promoting music niche tourism (case study: Isfahan, Iran)", Tourism Management Perspectives, Vol. 24, pp. 1-6.

Flessas, T. and Mulcahy, L. (2018), "Limiting law: art in the street and street in the art", Law, Culture and the Humanities, Vol. 14 No. 2, pp. 219-241.

Forte, F. and De Paola, P. (2019), "How can street art have economic value?", Sustainability, Vol. 11 No. 3 , p. 580.

Free Tours by Foot (2017), "Berlin graffiti and street art tour", available at: www.freetoursbyfoot.com/ berlin-graffiti-street-art-tour/ (accessed 11 November 2017).

Hanrahan, P. (1998), "Modern Trompe l'oeil", Visualization'98: Proceedings, October 18-23, Research Triangle Park, NC, p. 15.

Harvey, A.D. (2006), "Wall art in England", Critical Quarterly, Vol. 48 No. 1, pp. 68-79. 
Irvine, M. (2012), "The work on the street: street art and visual culture", in Sandywell, B. \& Heywood, I. (Eds), The Handbook of Visual Culture, Berg, London \& New York, NY, pp. 235-278.

Jażdżewska, I. (2017), "Murals as a tourist attraction in a post-industrial city: a case study of Łódź (Poland)", Turyzm, Vol. 27 No. 2, pp. 45-56.

Karimi, P. (2017), "Tourism, voyeurism and the media ecologies of Tehran's mural arts", in Skinner, J. and Jolliffe, L. (Eds), Murals and Tourism: Heritage, Politics and Identity, Routledge, North, Central \& South America, pp. 75-92.

Kihien, C.D.P. (2010), "Art in tourism, tourism in art. Breda university of applied sciences", available at: www.tourism-master.com/2010/10/31/art-in-tourism-tourism-in-art/ (accessed 23 November 2017).

Kosari, M. (2010), "Graffiti as protest art", Sociology of Art and Literature, Vol. 2 No. 1, pp. 65-102.

Lis, J. (2006), The History of 19th Century American Trompe L'oeil Artists and a Study of Their Preparatory Materials, Queen's University, Kingston.

Masoud, H., Mortazavi, M. and Farsani, N.T. (2018), "A study on tourists' tendency towards intangible cultural heritage as an attraction (case study: Isfahan, Iran)", City, Culture and Society, Vol. 17, pp. 54-60, doi: 10.1016/j.ccs.2018.11.001.

Mokras-Grabowska, J. (2014), "Art-tourism space in Łódź: the example of the urban forms gallery", Turyzm, Vol. 24 No. 2, pp. 23-30.

Molnár, V. (2018), "The business of urban coolness: emerging markets for street art", Poetics, Vol. 71, pp. 43-54.

Pinterest (2017), "Chalk street art - Kreidekunst", available at: www. pinterest.com/tollabea/chalk-streetart-kreidekunst/ (accessed 4 December 2017).

Robinson, M. and Novelli, M. (2005), Niche Tourism: An Introduction. Niche Tourism: Contemporary Issues, Trends and Cases, Elsevier Butterworth-Heinemann, Oxford, pp. 1-11.

Robinson, P., Heitmann, S. and Dieke, P.U. (Eds) (2011), Research Themes for Tourism, CABI, Oxford.

Rojo, J. and Harrington, S. (2014), "Exploring Lisbon as a street art tourist", available at: www. huffingtonpost.com/jaime-rojo-steven-harrington/lisbon-street-art_b_5611789.html（accessed 4 December 2017).

Rolfs, E. (2018), Parallel Tracks: Three Case Studies of the Relationship between Street Art and US Museums in the Twenty-First Century, LA State University and Agricultural and Mechanical College, Baton Rouge.

Ronen, R. and Biberman, E. (2005), "Who is deceived by Trompe L'Oeil?", in Tymieniecka A.T. (Ed.) Human Creation between Reality and Illusion. Analecta Husserliana (The Yearbook of Phenomenological Research), Springer, Dordrecht, Vol. 87.

Sandelowski, M. (1995), "Sample size in qualitative research", Research in Nursing \& Health, Vol. 18 No. 2, pp. 179-183.

Skinner, J. and Jolliffe, L. (Eds) (2017), Murals and Tourism: Heritage, Politics and Identity, Routledge, North, Central \& South America, p. 320.

Stewart, J. (2008), "Graffiti vandalism? Street art and the city: some considerations", The University of Melbourne Refereed e-Journal, Vol. 1 No. 2, pp. 86-107, available at: http://education.unimelb.edu.au/ data/assets/pdf_file/0003/1105752/jeff-stewart.pdf

Torabi Farsani, N., Saffari, B., Shafiei, Z. and Shafieian, A. (2018a), "Persian literary heritage tourism: travel agents' perspectives in Shiraz, Iran", Journal of Heritage Tourism, Vol. 13 No. 5, pp. 381-394.

Torabi Farsani, N., Zeinali, H. and Moaiednia, M. (2018b), "Food heritage and promoting herbal medicine-based niche tourism in Isfahan, Iran", Journal of Heritage Tourism, Vol. 13 No. 1, pp. 77-87.

Tsilimpounidi, M. and Walsh, A. (2011), "Painting human rights: mapping street art in Athens", Journal of Arts and Communities, Vol. 2 No. 2, pp. 111-122.

Yan, L., Xu, J.B., Sun, Z. and Xu, Y. (2019), "Street art as alternative attractions: a case of the east side gallery", Tourism Management Perspectives, Vol. 29, pp. 76-85. 


\section{About the authors}

Zahra Nikoo is a Master's Student in Tourism at Art University of Isfahan, Isfahan, Iran. Her research interests are painting and Trompe l'óil.

Neda Torabi Farsani is a Professor in Tourism, Art University of Isfahan, Isfahan, Iran. She received her PhD degree in Tourism in 2012 from the University of Aveiro, Portugal. She has also some papers in the fields of tourism published in international conferences and journals. She has been involved in writing several book chapters, and she is the editor of the book entitled: Geoparks and Geotourism: New Approaches to Sustainability for the 21st Century. Her research interests are geotourism, niche tourism, art tourism and cultural tourism. Neda Torabi Farsani is the corresponding author and can be contacted at: n.torabi@aui.ac.ir

Mohamadreza Emadi is an Assistant Professor at the Department of Visual and Fine Arts, Art University of Isfahan, Isfahan, Iran. He received his $\mathrm{PhD}$ degree in research art from Tehran University of Art, Iran. His research interests are painting, Iranian painting, wall painting and design.

For instructions on how to order reprints of this article, please visit our website: www.emeraldgrouppublishing.com/licensing/reprints.htm

Or contact us for further details: permissions@emeraldinsight.com 